Techniques \& Culture

Revue semestrielle d'anthropologie des techniques

28 | 1997

Accès aux savoirs d'autrui

\title{
A propos de Babbage
}

\section{Charles Kanelopoulos}

\section{OpenEdition}

Journals

Édition électronique

URL : https://journals.openedition.org/tc/471

DOI : $10.4000 /$ tc. 471

ISSN : 1952-420X

Éditeur

Éditions de l'EHESS

Édition imprimée

Date de publication : 1 novembre 1997

ISSN : 0248-6016

Référence électronique

Charles Kanelopoulos, «A propos de Babbage », Techniques \& Culture [En ligne], 28| 1997, mis en ligne le 28 octobre 2005, consulté le 29 septembre 2022. URL : http://journals.openedition.org/tc/471 : DOI : https://doi.org/10.4000/tc.471

Ce document a été généré automatiquement le 29 septembre 2022

Tous droits réservés 


\section{A propos de Babbage}

Charles Kanelopoulos 